\title{
The teacher of religion - missionary and evangelist, but also a professional and expert. Above all, however, a Christian experiencing a deep internal relationship with God through Christ Ludmila Muchová
}

\section{Introduction}

In Czech scholarly literature, there has been an interest in the personality of the teacher of religion during recent years. It has often focused on the specific personal profiles of important teachers or catechists. ${ }^{1}$ The question of what characteristics can be found in the personalities of contemporary Czech teachers of religion (28 years since the teaching of this subject was restored in Czech schools) remains in the background. I asked myself this question (inspired by the interest of my colleagues - leisure time teachers at the Department of Pedagogy at the Faculty of Theology). They were specifically interested in the personalities of leisure time teachers and their characteristics. It drew my attention towards the research deficit in this subject.

My research question is: What essential characteristics can be currently found in the personality of the teacher of religion in the Czech Republic? While seeking answers, I want to choose a theoretical framework based on a normative view and an empirical view of two German authors, supplemented by two smaller scale pieces of research with a similar topic in the Czech Republic. After this analysis, I will describe the qualitatively oriented research probe which I conducted in the spring months of 2017 within the Roman Catholic Church (in the South Bohemian diocese). I will use the method of analysis and interpretation of one interview in a focal group of teachers of religion. Its findings will then be compared with the results of the empirical research (quoted in the chapter defining the theoretical framework of work).

\section{The theoretical framework for a qualitative probe into the personality characteristics of the Czech teacher of religion and his or her role in society and the Church}

The normative view of the catechist's personality is represented (in the Czech environment) by Drímal and Alberich, who refer to the situation in which the catechist's role in the Church is mixed with the role of the religion teacher in the school. According to them, the catechist (and to a certain extent, by analogy, the teacher of religion as well) is responsible for his or her activity

1 Cf., for example, Ludvík DŘíMAL, František Tomášek jako katecheta dětí a mládeže, Olomouc: Matice cyrilometodějská, 2002; or Marie ZIMMERMANOVÁ, ThDr. Josef Hronek jako katechetik a pedagog, Praha: Karolinum, 2012; or Ludmila MUCHOVÁ, Solidarita otřesených - životní cesta a odkaz P. Pittra naší době, Theologia vitae 2/2015. 
at the base level (the middle level of responsibility is held by the vicarial catechetical and pedagogical centres, and the higher level belongs to the heads of catechetical centres at the diocesan level, to priests and bishops and to teachers responsible for the education and further education of catechists and teachers of religion). In relation to the personality of catechists, they speak about so-called 'catechetical competence.' This is reflected in three dimensions: the dimension of being, natural maturity, and maturity in faith. The natural level assumes an emotional balance, manifested (for example) in the ability to accept criticism, the unity of thoughts, words and deeds, to conduct a dialogue, etc. Maturity of faith is manifested both by their teaching and by their own lives, not only in relation to the faith itself, but also to the Church. The second dimension is the dimension of knowledge, which lies both in the knowledge acquired in the areas of partial theological disciplines and in sensitivity to the pastoral needs of the Church (in the context of the society in which they live and work). Part of this dimension represents the dimension of experience. This assumes experience in the mediation of knowledge (such as the biblical content and tradition of the Church, and the current social situation). The third dimension is the dimension of skills, which includes primarily professionalism. Professionalism is a prerequisite for the educational and communication impact of the catechist. Drímal and Alberich highlight skills that support the development of good mutual relationships in groups. They call them 'animation.' This brief description of catechetical competence is rather normative, referring to the General Directory for Catechism. The authors do not study the real conditions in which the teaching of religion and catechesis in the Czech lands takes place. Their brief analysis shows that the catechist's work (like the work of a religion teacher) should link high-quality personal maturity, Christian depth, and professionalism. How does this general idea correspond to real reality? From the results of my quantitative survey (conducted in 1999 in the diocese of České Budějovice), I would like to mention the following results.

Only $25 \%$ of the teachers had university theological education, $22 \%$ attended a non-theological university. Undergraduates showed a comparatively small number of hours of teaching, the same as high school students. The school environment perceived $75 \%$ of religion teachers as friendly (on a scale from slightly friendly to very friendly), but they did not have the illusion of having some influence on it. They were mostly looking forward to the lessons, and (especially) to meet the children. Only $17 \%$ of teachers were worried about the result of the lesson, and $16 \%$ of them were uncertain of their own abilities. South Bohemian religion teachers were also very pious. They often prayed on the way to school and found the power for their work in their personal prayer $(31 \%)$, in a life filled with Sacraments $(23 \%)$, in communion with other teachers $(22 \%)$, less frequently in their life with their parish (15\%). They developed their personal spirituality in close contact with the Church - through spiritual renewal offered by the Church. They were far less willing to participate in the activities of continuing education (only 15\% were prepared to finish their university degree in the form of distance education, the same number being willing to participate in regular training courses in the diocesan city). The results of quantitative research have shown that the balance between the professional and spiritual competence of South Bohemian religious teachers has been compromised here. ${ }^{3}$

Seven years later (in 2006), we conducted research on religious teaching throughout the Czech Republic in the Roman Catholic Church and in other denominations. Among other things, em-

Cf. Emilio ALBERICH - Ludvík DŘÍMAL, Katechetika, Praha: Portál, 2008, pp. 189-193.

Cf. Ludmila MUCHOVÁ, Náboženská edukace v současné společnosti, Habilitační práce. Ružomberok: Pedagogická fakulta Katolíckej univerzity, 2007, p. 167. 
phasis was placed on the characteristics of the faith of religion teachers, their relationship to the institution of the Church, the school, and the society based on plural worldviews. ${ }^{4}$ Approximately half of respondents met the qualification requirement for teaching religion - university qualification - which was similar to the research results obtained in South Bohemia. Speaking about the characteristic of the beliefs of religious teachers, the overwhelming majority expressed a so-called orthodox attitude. This includes a literal understanding of the Bible texts at the same time as having a belief in God. At the same time, however, almost half of them proclaim the so-called 'second naivete, i.e., they expressed a symbolic understanding of the meaning of biblical texts while believing in God. But almost half of them disagree with this attitude. Their attitudes are therefore largely polarised, the first part being directed towards a faith based on a literal interpretation of the Bible (which is prone to fundamentalism) and the second part of belief being based on the biblical texts understood in their symbolic form. In relation to a society based on plural worldviews, Czech teachers of religion were in favour of catechetical-oriented teaching, that is, to strengthen the Christian identity of pupils within their own religion. If they considered the plurality of views and religions as enriching, they tended to respond to it in teaching by giving only information to the pupils, without the possibility of actually meeting it and interacting with it. In relation to the Church, the respondents were mainly active members of the Church. In relation to the institution that guarantees teaching (partly the Church, partly the school), almost a fifth of the respondents said that they were experiencing stress more often than rarely, and $20 \%$ reported a more frequent burnout state. Nearly $60 \%$ complained about the low prestige of their subject, and only $52.3 \%$ of the respondents were satisfied with the didactic materials for which the Church is responsible.

From both studies, it can be concluded that Czech religious teachers perceive their own professionalism, although they often do not meet professional education requirements. They also perceive their personal religiosity and can express it even in the life of the Church. But they are not too sure about the surrounding plurality of views and religions. They tend to teach rather in a form of catechesis, either unrelated to world-wide plurality, or only by providing objective information about other religions... They are somewhat insecure in their professionalism, somewhat neglected by the schools in which they teach, somewhat make the teaching closed to outside society, but firmly rooted in their church.

In some neighbouring countries, 'Religion' as a school subject does not have the same status as it has in the Czech Republic. The difference lies (above all) in the number of pupils and students who enrol, even when the subject is not mandatory. ${ }^{5}$ However, there is a similarity in the fact that the teaching of religion is of a confessional nature, and the church (together with the state) is also responsible for its quality and status. This is accompanied by a theoretical reflection of the role of religion teachers in society and the Church in these countries (for example, Poland, Austria, Germany, and Slovakia). In the United Kingdom, religion-related subjects differ in terms of their aims and content, so there is no point in comparing theoretical reflections on the personality and the role of religion teachers.

A large number of professional articles and studies on this topic can be found in German-speaking countries. In spite of the above-mentioned differences in the number of pupils in the subject of religion, there has even been a growing number of questions focusing on the personality and

4 Cf. Ludmila MUCHOVÁ - František ŠTĚCH, Rozpaky nad pluralitou v české náboženské výchově?, Studia theologica 2/2008, pp. $72-87$.

5 Cf. ( ) Jana SKOKOVÁ, Náboženství jako součást školní edukace v různých zemích Evropy (on-line). Diploma work, Faculty of Theology, University of South Bohemia in České Budějovice, 2012. Available at: http://www.vyzkum-mladez.cz/zprava/1476795788.pdf, cited $5^{\text {th }}$ June 2017. 
the role of religion teachers in the face of accelerating changes in European society and the declining interest in religion in recent years. Due to the large extent of studies and research, I have chosen only the views of two well-known religion educators in these regions. ${ }^{6}$

Norbert Mette distinguishes two basic categories of influences on religion teachers. ${ }^{7}$ The first is his or her individual attitudes, among which he mentions a professional manner and personal religiosity. The second is different social influences, such as school institutions and their culture, society as such, etc. Mette points out that all of these circumstances decisively influence the way of the religious teaching of a particular teacher. They are also mutually conditioned, and they are evolving along with the number of years of the teacher's practice. Such circumstances make it very difficult to investigate those influences. Mette considers three categories as essential: the influence of the school, the influence of the teacher's relationship with the Church, and his/her own religiosity (which is related to the character of his/her personality). Mette notes that in the school environment German teachers of religion most often follow the latest didactic principles that turn attention to the pupils. At the same time, they choose the methods of work that are based on Christian values, so that they aim to develop the deep humanity of the pupils in relation to the transcendental reality - to God. While working, they consistently follow everyday experiences of their pupils, reflecting upon these experiences with them in the light of the biblical message. They help pupils to discover and develop their own religiosity, to decide for their own existential attitudes towards transcendence. They also advocate for pupils' needs. That is why (in recent surveys) the subject of religion is among the favourite subjects and religion teachers among the most popular with pupils. At the same time, however, (related to PISA's comparative international surveys) they are confronted with attempts to reform education. These attempts are focused on the professional training of pupils. Religious teachers in the German-speaking countries are under pressure to clearly formulate (in their curriculum) the specific knowledge and skills which pupils will obtain in their subject with regard to their future profession. They must also give a definition of knowledge standards and other information. Teachers are also under great pressure regarding the effectiveness of their teaching. This, according to Mette, may be a challenge for teachers of religion to clearly formulate a specific 'standard' leading not only to an honest attitude towards the future profession of the pupils, but also to the ability of living together with people with different lifestyles, and leading to the attitude of responsible subjects who have a clear, humane vision of the future world. However, they find themselves in a certain tension between bringing up the pupils and the specific educational task. Similarly, teachers of religion in our country could encounter similar tensions in the context of the 2004 school reform. The professional aspect of the work dimension of a religion teacher therefore carries the tension between the direction of the EU school systems towards the increasingly sophisticated professional orientation of pupils and the Christian view of the value of life itself which comes from the origin of man and the world from God, not from his or her success or failure in the market. In relation to the Church, Mette points out that the teacher of religion does not simply represent the extended hand of the Church in the school, nor does he/she put the catechism into practice at school. The reason is the distance

6 There are studies which have originated both in the Catholic as well as the Protestant framework of religious education in the last 10 years, such as Hans Mendl (Passau), Martin Rothangel (Wien), Hans Georg Ziebertz (Würzburg), and others. Given the scope of this article, I chose only two authors, who put their own research into a historical framework. It should be noted that recent literature (of the past ten years) has commented on categories similar to those described by the two authors in their research more than ten years ago.

7 Cf. Norbert METTE, Zum Beruf und Selbstverständnis von Religionslehrern und - lehrerinnen im Kontext aktueller Entwicklungen in Gesellschaft und Schule sowie Religion und Kirche, Christlich pädagogische Bletter 3/2004, pp. 134-136. 
between school and the Church space which has been set up by European development in recent centuries. Thus, in the area of the Church, it is mainly about the development of the children and young people's Christian attitudes in connection with the faithful life of the whole believing community (i.e., a parish). At school on the other hand, it is about the development of the Christian attitudes of children (combined with the understanding of Christianity and religion). These enable them to adopt their own attitudes towards religion based on the ability to evaluate or judge. The goal of religion teachers in schools is to help pupils know the contents of the Christian faith and understand the language they are expressed with (so-called religious literacy). Religious teachers, however, often come to the point that the described approach towards the school environment is not trusted by official church leaders. On the other hand, they become the closest target of criticism both for pupils and for colleagues. Teachers find themselves in difficult situations when they are confronted with (in their own view) bad or incomprehensible Church actions (in the Czech context, it could be the restitution of ecclesiastical property, affairs of homosexual priests, etc.). German research shows that religious teachers themselves are often very committed to their church. They have a critical but loyal attitude. They experience tensions between their own attitude and expectations in connection with the Church (trust, support), but they receive distrust and criticism with a portion of prejudice. In addition, religion teachers are often considered to be the experts on world religions by their colleagues and pupils, and they also encounter a series of prejudice in this context. However, they do not always feel sufficiently educated to be able to really help (using their expertise) because they have not obtained it in preparatory studies. Even this tension between the expectations of expertise in general religious issues and the readiness for it can often be seen in interviews with Czech teachers of religion.

In the third category (called the Christian attitudes of religion teachers) Mette refers to his own qualitatively oriented research among teachers of all levels of education. It shows that religion teachers have (in comparison with other teachers) different motivations for their work and experience their subject as a challenge in a somewhat different sense. ${ }^{8}$ In this subject they cannot hold a neutral position. The children ask about their relationship with God, Christianity, and the Church. They expect authenticity in the teacher's relationship to the Christian faith. Teachers may feel unnecessarily overloaded by this unspoken demand. They cannot distinguish between their authentic Christian faith (in which they can find themselves in crises) and the objectively reflected faith which is then represented to their pupils. At the same time, they must not become the uninvolved distant observers of religion. The personal history of their relationship with God is an important part of teaching. According to Mette, (in addition to thinking about one's own beliefs which should be practiced by every believer) the teacher of religion should be able to 'reflect this reflected faith' in order to be able to use it in a didactic way. As a didactic use, Mette understands the goal of creating a balance between the reflection of one's own faith and the reflection that he or she wants to give to his pupils in relation to their own faith. This is an objective which did not have to be pursued in past times (that is when Christianity represented the general attitude of society members towards life). In a religiously plural society and a state with a neutral attitude towards all worldviews, however, this is an important service to pupils. ${ }^{9}$

Mette therefore perceives the position of a religion teacher at a school for the public as a position containing a series of tensions:

8 Mette cites the reference to research published in the book by Saskia HÜTTE and Norbert METTE et al., Religion im Klassenverband unterrichten. Lehrerinnen berichten von ihren Erfahrungen, Münster: LIT Verlag, 2003.

9 Cf. METTE, Zum Beruf ..., pp. 134-138. 
- In relation to the educational system, there is a tension between educating for a deeper experience of one's own humanity and the narrow requirement to prepare them for future professions;

- In relation to the school where they work, there is a tension between the expectations of colleagues and pupils (religion teachers are seen as experts on issues related to world religions) and their own inadequate education in this respect;

- In relation to the Church, there is a tension between the aim to lead pupils towards the understanding of Christianity and towards making their own decision and the Church's expectation that religion teachers will primarily provide pupils with a certain amount of confessional knowledge;

- In relation to one's own beliefs, there is a tension between their own living religiosity and the reflection of this faith seen from a distance (so that it can become part of the teaching).

Thus, according to Mette's study, religion teachers experience their professionalism as a strain in relation to the objectives of school education and in relation to their roles as experts. The role of a witness of faith and missionary is expected by the Church. This dimension of their role can bring some tension also. Mette's interpretation gives us a certain knowledge. It points out that a religion teacher should be an educated professional - both in the field of ecclesiastical teaching and in broader religious areas. He or she should be able to evaluate his or her own professionality. This, of course, must also apply to Czech teachers of religion, except that the subject of religion is either totally absent in many schools (because of the small number of enrolled pupils) or is taught in the afternoon when other teachers leave the school building. Czech teachers of religion then often suffer from a rather marginalised position of their subject within the school. Which, however, does not exclude the fact that their colleagues - teachers - will not ask questions about Christianity and the Church at all. They meet a homeroom teacher in the classroom where they teach, and they also have occasional contact with school management, etc.

F. Schweitzer ${ }^{10}$ (in the German-speaking countries) believes that it is somewhat dubious to call religion teaching a profession, especially because religion teachers themselves (at the same time) bring alternatively oriented religious and educational activities. In the role of religion teachers, there appear priests (in the Evangelical church, to which F. Schweitzer belongs, these are pastors) who are also responsible for other pastoral services. Also, so-called lay religious teachers (in addition to teaching at school) also work as catechists in the parish. There they work with other age categories: adults, seniors, sick, etc. Moreover, they do not always receive wages for those parish activities. Schweitzer therefore points out that the job of religion teachers in Germany cannot be considered in the same way as other regular jobs due to the lack of specific professional focus, that is, the kind of specific professional focus which would develop within a single profession and would be the source of their livelihood. If this is the case for German countries, it is twice valid for the conditions in the Czech Republic and the religion teachers who live there.

Schweitzer put questions about the tensions arising from specific expectations (that is, the religion teacher has to be a teacher-professional as well) in the 1970s. The pupils' expectations were mainly studied. Research has shown that children and young people are interested in religion as a subject if it is related to problems in their personal lives. On the other hand, they were much less

10 Cf. Friedrich SCHWEITZER, Religionspädagogik. Lehrbuch PraktischeTheologie. Band 1, München: Gütersloher Verlagshaus, 2006, pp. 185-196. 
interested in Church teaching and Church tradition. Significant was the relationship of religion teachers to curricula. In particular, religion teachers perceived their subject as a legitimate subject through the curricula. That made them feel responsible for teaching regarding school management, inspections, the legal status of the subject, etc. Surveys also showed surprisingly high scores in evaluation (of the subject and the level of teaching) by parents of pupils, who (at the same time) expected a significant contribution to the positive existential values of their children. However, different groups of parents had different expectations (in relation to the mediation of religious content) depending on how close or far they felt they were towards the Church. Another important category (in the various research carried out) was considered to be a category called the expectation from the state. In the 19th century, there was the expectancy from religious education to support values leading to loyalty to the state. In the last decades, it was added (as an important category) to the educational contribution towards multicultural and multireligious peaceful co-living in society nowadays. The churches describe their expectations connected with the teaching of religion in public schools in their documents. Catholic religion teachers should follow the General Directory for Catechism, which clearly shows the difference in the teaching of religion versus Church catechesis. It is true, though, that the religion teacher needs a Church mandate to teach religion. In this way, the Church makes sure that the teachers of religion are its active members. The final important category is the influence of religious pedagogy as a science. It is suspected of shifting the emphasis away from confessional content towards educating the person in a general way. In response, there is a need to formulate more precisely defined competences and standards for religion teaching. We also see this trend in the Czech Catholic Church.

Since the 1980s, according to Schweitzer, research related to the relationship between the religion teacher's role and his or her personal history and religious orientation (his or her religiosity) has been gaining importance. It was not, however, the creation of the ideal image of the religion teacher (as suggested by, for example, the authors Drimal and Alberich in relation to the personality of the catechist), which is demonstrated in his or her personal life. It was rather about the research that deals with the relationship between his or her individual life history and his or her possibilities to be a good religion teacher. These were life events, such as psychological injuries or their own borders. All this was connected with a new term 'the professional identity of a religion teacher'. Schweitzer summarises a large number of both quantitative and qualitative surveys and specifies that the following trends that have emerged:

Quantitative and qualitative surveys of the professional satisfaction of religious teachers have shown both external factors (positive - the acceptance of the subject by the leadership of schools and colleagues, but also negative - such as the lack of religious family socialisation of pupils) and internal factors based on the attitudes of teachers themselves towards religion and towards the teaching of the subject.

Qualitative research (mainly case studies) have contributed to the knowledge of the importance of personal biography as a prerequisite for the professional identity of the religion teacher. This has shown both the importance of the teacher's attribution with a certain age cohort and, consequently, the impact of social events on his or her personality (in the Czech context, it could be the experience of the Second World War, the persecution of the Church during socialism, the Velvet Revolution, etc.) and individual experiences (for example, meeting with a particular teacher of religion in childhood, with a priest who motivated young people to work for the Church, etc.). The lived and taught religion are two categories which have been described by different research. The religiosity lived and realised by teachers in their personal lives is not wholly mediated to 
pupils. By using professional and continuing education, the teacher needs to gain a view at a distance from his or her own life experiences (which have influenced his or her religious beliefs) and transform them into a form that can be mediated to pupils at the right time (that is, when he or she knows the relation of those experiences towards the content and the goal of education).

The attitude towards the Church is a category that was (particularly in the German-speaking areas) the source of concerns. There has been a fear that religion teachers have been becoming more distant from the Church. In the Catholic setting, however, it has been shown that (among the teachers) there is an increase in those who actively participate in the life of the Church as well. In the Czech environment, this category is 'pre-treated' by a specific mechanism. Teachers have to request a canonical mission where his or her active relationship towards the Church is confirmed by a priest.

The reflection of teaching objectives by teachers themselves (according to these pieces of research) does not always correspond clearly to their determination by religious-didactic theories embodied in the curriculum documents. It is subject to other factors - for example, the uncertainty in the formulation of research goals in the former East German lands may indicate the didactic uncertainty' of religious teachers. That uncertainty is related to the relationship between Church, school, and Christianity itself.

Schweitzer briefly refers to the research which (instead of the question regarding how religion teachers perceive themselves) was solving the question of what the Church and the pupils themselves expect. He cites the research that showed the pupils' need for greater personal attention and for the self-presentation of religion teachers as models for child/youth life. Pupils expected the subject to allow them active participation, to be full of dynamics and changes, to be oriented towards their real life. Schweitzer (as a result of research in the 1980s) concludes that the professional identity of the religion teacher is related both to the development of his or her religious belief in his or her particular life and to the knowledge and understanding of the contemporary life of children and young people.

In recent years (according to Schweitzer), the concept of 'professional identity' has been replaced by the term 'professional competence' of a religion teacher. It is related to the pressure that is generated due to the international comparative tests of school performance (PISA, etc.) in school education. In connection with them, competencies (concerning pupils' key knowledge and skills) have first been developed. After that, the competencies of the teachers (who should lead the pupils towards those skills and knowledge) were derived. And teachers should obtain the competencies through the teachers' education system. To control pupil competencies, there is a system of standardised tasks which pupils have to solve in order to demonstrate the acquisition of the competencies. This trend has also been accepted by the Czech national curriculum (see the Framework Education Programme for Basic Education ${ }^{11}$ ). Its logic is also followed by the recommendation of Catholic diocesan catechetical centres, which impel the creation of school education programmes as attachments to, or direct components of school educational programmes. Schweitzer refers to the criticism that this system faces from some educators. It is seen as a system focused unilaterally on the performance of pupils. In our conditions, we can refer to Skalkova, for example. ${ }^{12}$ Yet attempts are also being made to formulate specific pupils' competencies in religious education. It happened, for example, in the draft of the Czech Church document. It regulated (methodically)

11 Cf. @ RVP ZV (on-line), available at: http://www.nuv.cz/uploads/RVP_ZV_2017.pdf, cited $3^{\text {rd }}$ June 2017.

12 Cf. Jarmila SKALKOVÁ, Za novou kvalitu vyučování, Brno: Paido, 1995. 
the religion teaching at Czech Church schools in 2016. However, it was not accepted by the Czech Bishops' Conference.

Schweitzer sees (with reference to relevant research in the second half of the $20^{\text {th }}$ century and the beginning of the $21^{\text {st }}$ century) the development of the professional identity of religion teachers as a process that has gone from the simple perception of the role of religion teacher towards pupils, school, church, and his or her own religiosity (in fact, towards the similar areas described by Mette) to the perception of professional identity as a competence derived from the specific competencies (those which he or she should lead the pupils to). In other words, at the forefront of research questions there was no attempt to capture the perception of the professional identity (by religious teachers themselves), but how the identity is seen in the context of the named related areas. It draws attention to the fact that (even in German-speaking countries) the educational professionalism of religion teachers differs from other disciplines. It is given by the fact that (even here) religion teachers also volunteer in other areas - for example, in the Church - and these two fields cannot be completely separated from each other due to their similar engagement.

Thus, (according to Mette) the professionalism of the religion teacher is in coping with the roles (in the midst of tensions arising from the expectations of various co-authors of this type of education), Schweizer's version of the professionalism of the religion teacher is expressed in his or her competence to form the pupils' competencies. Schweitzer disputes the nature of the pure professionalism of religion teachers when he draws attention to activities that are related to the teaching of religion but are of a non-professional character. These authors also suggest that the work of a religion teacher is not just about professional identity itself but also about other characteristics such as to be a witness to the faith and to be the one who mediates the faith to the pupils or at least helps them to gain experience in a multi-religious and plural contemporary world, and helps them to perceive such a world as a challenge for their lives. In this language area, we can talk about the religion teachers as professionals, witnesses of faith, and missionaries. They are those who, with understanding and sensitivity, open up questions of faith for their pupils and students. At the theoretical level, this understanding of the teacher's personality cannot be compared with the results of relevant Czech studies or research, although the two described above also point to similar categories that appeared in the analysis of the cited authors in the German-speaking field. These are the perception of the religion teaching as a profession, as a task given by the Church, and as an activity based on personal religiosity carried out in certain narrow school and wider social conditions. This we can understand as a challenge (based on a simple qualitative inquiry) to find among Czech teachers the understanding for their own identity (as teachers) and to describe it in a differentiated way.

\section{Qualitative Research (Focal Group)}

The methodological framework of the described qualitative probe into the characteristics of religion teachers' personalities was chosen in the form of analysis and interpretation of data from the discussion in one focal group, according to the principles of D. L. Morgan. ${ }^{13}$

\section{Focal group characteristics:}

I asked the vicariate coordinators of catechetical and pedagogical work (in the Roman Catholic Church diocese of Ceske Budejovice) to make contact with teachers of religion that they knew

13 Cf. David L. MORGAN, Ohniskové skupiny jako metoda kvalitativního výzkumu, Boskovice: Albert, 2001. 
from their own teaching practice. The final focus group consists of 11 members, who were more or less familiar among themselves (which is against Morgan's empirical rules). Complete anonymity would be difficult to secure due to the small number of religious teachers in the diocese of Ceske Budejovice. For individual members, I give their (invented) first names and the length of their practice:

$\begin{array}{lr}\text { Libuše } & 26 \text { years } \\ \text { Lucie } & 26 \text { years } \\ \text { Monika } & 15 \text { years } \\ \text { Václav } & 26 \text { years } \\ \text { Mirka } & 6 \text { years } \\ \text { Bára } & 25 \text { years } \\ \text { Lýdie } & 24 \text { years } \\ \text { Marta } & 1 \text { year } \\ \text { Sofie } & 9 \text { years } \\ \text { Magda } & 20 \text { years } \\ \text { Helena } & 21 \text { years }\end{array}$

According to the survey, only one participant belongs among the religion teachers who are starting out, only two have less than ten years of experience, five have from 11 to 25 years of practice, and three more than 25 years. This means that (except for one) these are teachers who have proven themselves over many years of practice. This fact can of course influence the view of their own profession, which might then seem to be the homogeneous view of these 'old practitioners'. This fact moves the validity of the research probe but does not discriminate against it.

The questions and the course of the interview:

In accordance with D. L. Morgan's recommendation (after the creation of a theoretical framework for a qualitative probe), I formulated five basic questions, at a very general level. I chose the 'funnel' method, so the first very wide-ranging question had the task of stirring up the debate. It sounded like: 1 . Why did you ever become a teacher of religion? There were three more specific questions: 2. How do you perceive yourself as a teacher?, 3. What is important for you (as a religion teacher) in the school environment?, and 4. Are you a satisfied religion teacher? The final question was (in a somewhat more general way without 'forcing' my own views) directed towards the Church: 5. What do you think of when the word 'Church' is said?

The conversation itself lasted 60 minutes (because the time for group participants to meet and know each other was not necessary) and it was situated in the Faculty of Theology (University of South Bohemia) social room. With the consent of the participants, it was recorded on a Dictaphone (with the assurance that, in the case of publication, first names would be changed to ensure anonymity).

\subsection{Analysis of the acquired categories and their interpretation}

I describe categories and partly interpret them in the logic of the questions that I asked the group during the interview. 


\subsubsection{The Religion Teacher - External and Internal Motivation for the Work - or 'Why it Makes Sense'}

The first (introductory) question was trying to provoke the broadest possible discourse of the participants about their motivation to work as religion teachers. I also expected them to (spontaneously) touch upon the areas which are associated with their teaching engagement (profession, school, and Church).

The teachers spontaneously spoke about their motives for work. They stated both the outer immediate impulses and the deep inner motivation. The external impulse was most often (at the beginning of their work) the request from the priest (Vaclav: ... then the particular request from the dean: You will go to teach at school ...) or the need of a colleague (Marta: My friend, who taught religion, started her maternity leave and said - you could go to the school, it was an optional class ...). Often it was also the need of faithful families in the parish (Helena: ... it is also at the request from the families in the parishes, the faithful families. They expect it from us, they expect service from the Church ...). In other words, it is rather an informal situation when the need to become a religion teacher grows out of the need of the Church (not as a fulfilment of professionally oriented study). The Church is perceived as a community and they feel a part of it. An important external motive is meeting children and their world: 'When I am sometimes tired, they bring a little thing, something that encourages me and helps me to continue in my work' (Mirka).

Inner motivation is described by most members of the group as an emotional experience which they rationally interpret (Monika: Many of us feel that it is a kind of a mission ...). They do not only see their work as a profession, but as a mission, a calling (Bára: It is such a calling for a person to decide to go this way ...). They perceive the parish service as a commitment. The fundamental inner motive (for the members of the group being studied) is their own inner focus (Frankl's interpretation) on the meaning of life. As Marta says: 'I found ... when I accompany someone on his or her way to God, I am enriched. I am always enjoying it because it enriches me.' They are able to overcome the obstacles - fatigue, misunderstanding, or fear of not being self-sufficient. Meetings with the world of children (in the perception of religious teachers among the members of the study group) are deepened by their focus on children's faith. But this starts with spontaneous attention to pupils' existential experiences (so Lucie 'was sad' with one girl (whose grandfather died) for an hour ... but it was amazing how the children behaved, the little girl wept, so we were with her and were praying for her grandad, so it was ... so beautiful, no one laughed, children were talking about how they experienced it when somebody died, and that cannot be planned ...) through the evangelistic focus (Vaclav: It was such a desire to give spirituality, in fact the gospel ...), to the mutual touch of the world of the teacher's faith with the faith of the children. So, Václav sometimes has the feeling that: 'I do not teach children, but my children ... I touched the truth of the faith - but it touched me too - and suddenly I realised - aha, here's something alive ... because they react to a topic and are able to take something in a real way ...' Or Marta, who is an introvert and she has a problem to talk about such personal things connected with God, has suddenly begun to talk about such matters during the teaching of religion. The most important internal motive of the group of teachers studied is that they influence children's faith, although they distinguish between the purpose of religious teaching at school and catechesis in the Church. For example, Magda says, 'I cannot just build such a high level that I will teach the children and then they will live like Christians and come to the kingdom of God because I have taught them something ... I would have to just leave it. But for me, it is such a level that I take care of those children, for a time, that God gives me this responsibility to accompany them, and I wish they once will remember that ... God 
is on their side that (it is like) they do matter to Him, that he knows them well. I do not want them to remember me but God, and to remember Him that he simply is, and that they can turn to Him, when it is necessary to make decisions or to go through some tests or joys ...'

\subsubsection{The Teacher of Religion - a Gospel Announcer and a Kind Guide 'Under Difficult Conditions'}

The second, third, and fourth questions concerned the relationship of the group members towards their own role of the religion teacher in the school environment. In the discussion, the teachers mainly distinguished the external features of their teaching role. In those, there was consent with other teachers. This was mainly about the teaching itself and its administration (Marta had to learn how to operate with an electronic class book, and Lydia adds: But I really feel like a teacher only when I write a class report, reviews, notes into pupils' books, tests and when I correct students' work...). They have more carefully defined how their status differs and it is worse (in comparison with other teachers). It is that way especially in organisational conditions (so Marta has children from the 1st to the 5th grade and Libuše says: I teach at 4 schools. It is always so similar, every school year. Sometimes it turns out that I have to teach at five schools during one school year ...) and in the financial reward for their work (Libuše says: ... I will do the work here, but am I paid for it? - that's a question - certainly just enough to create the labour contract. They raised my salary at some place. The hourly wage has to be about $120 \mathrm{CZK}$, so they gave me the raise and I was pleased. And then I found out it was a five crown raise, so that is a question ...). They also defined the specific features of the religion teacher's role. They sometimes appear to their colleagues as the experts on religious issues (Marta: Other teachers suddenly came to see me and wanted some advice ...). As believers, they perceive themselves as representatives of the Church and proclaimers of the Gospel. Magda points out that it is not just a certain number of hours in that school, but somehow to represent us, believers where people live ... to proclaim when it is necessary or when we are asked to do so ...).

Substantially more engaging and spontaneous were the group members towards the problem of their relationship to the school climate. One direction of reasoning described this relation primarily as a relation shown by school leaders and colleagues towards the religious teachers. Here they perceive friendliness (Bára, for example, as follows: This is how the teacher (who is in charge of this school) refers to me: children, this is our teacher. Are you already looking forward to her? She is going to come for Christmas or she is going to come back for Easter ... We are already counting on you, just like that). Sometimes the religion teachers are not (at all) sure of acceptance or denial (Libuše has been teaching for 25 years and at one school only she was on the teachers' list on its website. It was thanks to a deputy director who wrote her name there. When this deputy retired after two years ... her name disappeared). Some of them are certain that they are not accepted as teachers (I do not think that there is equality with the other teachers here ... Lucie). As a second topic, members of the group created a link to the question of how they themselves affect the climate of the school. It can be summarised as a harmonising task in the school climate. Lucie describes it well - as a role of a kind confidante (But I think we have another task. I do not think about it in a bad way because our position is a bit different. When I put it a little bit stronger, it is like to be a mum there ... I will give an example: one teacher's mother died and he accepted me as his mother. We talk together that way, we have that kind of a relationship. Or Libuše: I like that they perceive us as someone who carries something higher, different. They see us as a sponge that also swallows what hurts ...). If they come into conflict with school management, it can be resolved. They just 
need the courage to defend some children's rights - Magda: 'As a religion teacher, I once entered a dispute with the director because we touched on something I did not like. At the end of the year, I did not like how one of the teachers used the leisure time for pupils (the time when they do not have to learn). I would not have known about it if the kids had not told me... And the kids wanted to go elsewhere and do something else, but they were told (by this teacher) that it just had to stay that way because they democratically voted...'

When talking about satisfaction with their own pedagogical role, the members of the group surveyed mostly had negative feelings. These were mainly their own tiredness and the non-acceptance by others (Václav: I would say that, after so many years, I feel quite tired and disappointed with such non-acceptance. That things just do not go the way they should) and their own feeling of insufficiency (Lucie: ... if it does not work, when it gets stuck or one cannot manage it, then one is disappointed...). There is significant differentiation among them when talking about the insufficient appreciation from their own Church. They formulate it at the general level (Magda: I would say that I do not feel supported sometimes, and that I feel rather sorry. It is not because of myself. I feel like that because this is the general trend in the Church. One cannot find appreciation or encouragement, giving of thanks or motivation ... because our work is taken automatically as a service ...) or at a very specific level (Marta: I do not like that fact that sometimes the priests see us as weird. I have a feeling that they see us lower than themselves. That is what bothers me more ...).

For the first time, there is also a negative feeling of experiencing the crisis in the Church (Marta: How to keep faith ... really... Sometimes it is as if it cannot be at the same place, God and the Church. Jesus creates the Church and people as well. But now I have such a...). One of them identified positive feeling. It describes gratitude for having a profession which gives sense to life (Marta: ... So, we are happy, in what we do... and with the children...surely yes...; Václav: But on the other hand, I feel so deeply grateful for this job, that I could have done this all the time, and I can still do it and I will even in the future). And (once again) they came back to the statement that they are particularly satisfied with the meaningfulness of work which opens and brings the faith to school children.

\subsubsection{Teacher of Religion and the Church - Like at Home in the Family: in the Joys and Fears}

To a very general question about the relationship of the members of the group to the Church, the participants responded with a discourse in which they distinguished the category of the local Church and the generally understood Church. In addition, they contrasted their perception of the Church as a family or, more generally, a community with the Church as an institution. The perception of the Church analogous to the perception of one's own family was connected with the local church (Libuše: For me, the church, and I mean the local one, the one which is closest to me, so for me the church means the family). First, it was defined statically - as a hierarchically structured family community (Magda: It could be expressed as a family, but in the family I see the hierarchy - father and mother, those authorities, obedience, but sometimes the hierarchy in the Church tends to get overestimated a bit ...), and dynamically - as a guide to their own lives (Libuše: So I essentially grew up from the family of the Church. First of all, I was going to the parish with my family, then I was a part of it as a youth. Then we got the invitation to study at the Faculty of Theology - the vicar came to the youth community and said that we would support the faculty by going there... So it was as if I was chosen from that community. I felt like it was a real family. Or Sophia: I grew up in it too. I was raised surrounded by pilgrimage and diocese. I do not know any time without the Church.) For the members of the group, the local Church is a place of both shared joy and shared pain (Libuše: I must say that sometimes there is a lot of fun in the Church, yeah, if you ever see us at the parish, there is so much fun, 
yeah, that I cannot even say that ... but sometimes there really are times when things are hard, or you share the pain with someone, and - yeah, that is life and world ...). The Church is perceived at a general level and understood as something close to family - as a community where everyone has their place (Bára: And in the Church I am well. It is such an environment in which one has his or her place, or that he or she can live there - how can I describe it - it is just fine there. Helena says: Somewhere we have to have a background, a place where we come from. And when the background is good, we have something to pass back to that community ...). At the same time, they are insinuating the issues connected with the crisis of the institutional church (Marta: ... but I see it a little differently, like the two views. Firstly, I see it as a community of people who believe in one common thing and they just go for it. It is not the same for me as the institution of the Church though. There I see it differently. Moderator: There is crisis? Marta: Yeah, that is a problem a bit). However, their relationship to the Church does not originate primarily from the relationship to the Church as a community of people, or as a purely human institution. In the discussion, they admit having a very intimate and internal relationship with Jesus (Libuše: I have such a picture in the office on the desk, maybe someone thinks it is childish, but it is Jesus, with a crown of thorns on his head. He is bleeding, sweating, on the way ... so I imagine the Church this way. That it is full of pain, wounds, but inside it is not just that pain in Jesus, it is also that giving...). As soon as they encounter some negatives in their ' $\mathrm{Church}$ ', it is a challenge for them to share this problem with God (Libuše: I think that there is indeed the essence of the Cross here. Marta, on the other hand, perceives it as a painful time when she could not talk about her experience of the crisis phenomena in the Church. She says: When I experienced some pain in the church, I stopped talking about it with God, and it took a long time before I started to realise that it was a terrible mistake). Through his or her own profound relationship with Jesus, even in his and their situations of suffering, he or she understands the Church as the mystical body of Christ (Libuše: Christ says that he is the mystical body of the Church, that the Church is ... like his body). So - despite, or precisely because of the negatives that they experience in the institution of the Church - they paradoxically grow in love towards the Church even with its shortcomings and mistakes (Monika: Why do you do this? How many times have you seen appreciation? You work here very hard and no one helps you. But I found out that in these critical moments, when I'm tired and exhausted, I know that I really love the Church). This attitude then gives them the strength to remain in the Church as well as working as a religion teacher. For them, this job is understood as a mission given by Christ and it is expressed by the Church (Magda: I am glad to teach religion and it is precisely because it sounds as if the Church, as an institution, is in crisis,... One realises that in the Church, from the bishop to the laity, they are just people who have their limitations, their mistakes. I am glad that I can work there and try to do all I can to make the Church beautiful).

\section{Discussion}

If we compare the results of this qualitative probe into the personality characteristics of a Czech religion teacher with two cited German authors, we can state the following.

Although our questions followed Mette's three categories of influences (which have an impact on the personality of the religion teacher) very broadly, members of the surveyed group either created them ('the school climate') or developed them (the relationship towards the role of the religion teacher and the relationship with the Church) in the discussion. In our sample, religion teachers came together and the majority of them had had longer than ten years practising. So, it is possible that we captured the type of perception (of the professional identity of the religion teacher) which has been gained via longer practice. 
Research has shown one specific Czech factor - attention towards the pupils, which Mette has described only. According to our research, it is an important dimension of the teacher's personality, which fills his or her work with sense. On the contrary, our religion teachers have not spoken about any pressure which schools create in order to gain the measurable performance of pupils. This factor, described by Mette and Schweitzer, was not mentioned in the Czech environment. In relation to the teaching itself, Czech religion teachers also distinguish between school teaching and catechesis in the Church. Unlike German teachers, they define it theologically (in school as evangelisation).

In relation to their own religiosity (shown by Mette as the source of tension between 'living and taught religion') our teachers did not show any tension. On the contrary, teaching is the logical expression of their living religiosity.

Schweitzer points out that there are other characteristics of religion teachers (such as the history of their personal belief in secularising societies), apart from the 'main' professional identity derived from the ability of a religion teacher to fulfil pupils' competencies. This idea has provided an ultimately different result in our research probe. The essential characteristic of the Czech religion teachers was their own intense relationship with God through Christ, from which they derive both their ecclesial and professional identities.

Compared to the conclusions of two Czech pieces of quantitative research, we can conclude that the current qualitative probe has shown rather the certainty of religion teachers surveyed when talking about their own core personality dimension. It is identical to their relationship with God through Christ (from which they derive their greater self-assurance at the school). They do not see themselves as ordinary teachers at school, but rather as kind guides for both children and adults. They are quite sure about their role, and they are rather dissatisfied with the circumstances in which they have to teach, and sometimes also with their own borders. They do not consider the atmosphere of schools as an explicit rejection, the confidence in professionalism is provided by their own (theologically described) evangelical teaching objective. This one is based on the attention to children's existential experience. It seems (therefore), that (with the consideration of the previous two studies) there could have been a shift in the self-assessment of religion teachers: they derive their professionalism from the theologically perceived goals which (together with the response to the climate of the school and the climate in their own Church) they have built on a lively and intense relationship to God through Christ. They do not close themselves towards school and society. They rather enter it through their pupils and students in order to bring Christian spiritual values into it.

\section{Conclusion}

In the introduction, I asked this question: What essential characteristics can be found in the personality of a religion teacher at the present time in our country?

From the analysis of the discourse (that took place in the group examined), it is possible to actually portray the dimensions of the personality of the religion teacher. The essential dimension of his or her life as a whole (and hence his or her life in the Church and as a teacher of religion) is the spiritual core of his or her personality, which is identical to his or her deeply-lived inner relationship with God through Christ. It is the prism through which he or she perceives and experiences all areas of his or her life. In relation to the work of the religion teacher, this attitude is then reflected in two basic areas: Church and the school. 
The Church is perceived ambivalently both as a family community (in which they feel is an analogy to the family community and enjoy it joyfully) and as an institution that touches him or her from time to time with its moral failures. In such moments, he or she draws from his or her deep relationship with God in Jesus Christ, and he or she experiences these failures as the pain of the Church and his or her own, to which he or she responds with his or her own sincere engagement. At school, he or she sees his or her role as much deeper than just the teaching of a subject. He or she feels inclined to be a kind guide to both children in faith (in religion classes) and to their colleagues (in their lives) if they come into contact with them. From his or her basic attitude of deep faith, he or she spontaneously perceives his or her teaching role in relation to the aims and contents of teaching. This is the opening of the world of faith to children (with the sense for their existential experience in the contemporary world). In his or her own teaching role, however, he or she does not feel quite sure in the school environment. The teaching of his or her subject is marginal and organisationally difficult in school life. In addition, he or she does not perceive resistance towards religion at school and from colleagues but he or she is not always sure of his or her acceptance.

The second important dimension of the personality of the religion teacher (as revealed by this research) is the emphasis on the obstacles that the teacher of religion overcomes. He or she does that with spiritual focus on the value of the life sense. He or she sees its fulfilment then in opening the world of faith up to children coming from faithful families and also for those for whom the teaching of religion is their first encounter with Christian faith.

The attitude of deep faith (which in practice encounters a number of difficulties and obstacles for the teacher of religion in relation to the school and the Church) is a fact that needs to be taken seriously and developed in the training of future teachers of religion and catechists. However, due to the specificity of the profession of the religion teacher, it is necessary to realise this in the interconnection of personal, professional, and spiritual development. Various models of mentoring and supervision are available, which could be already included in the study programmes (in practice) at the faculties of theology. It could be followed by the offer of supervision for the professional and spiritual accompaniment of religion teachers. In Czech conditions, only the Ostrava-Opava diocese offers this in the Catholic setting.

Of course, the research probe in one focal group has an exploratory character, and the type of personality of religion teacher which it has displayed can be one of the many that occur in the Czech Republic. This may be influenced by, for example, the length of practice of the group members (people with the other types of personality may not solve the obstacles in the Church and the school environment from the spiritual nucleus and could interrupt the work and possibly life in the Church). In conversation with group members, however, this type of religion teacher was uniquely identified. 


\title{
The teacher of religion - missionary and evangelist, but also a professional and expert. Above all, however, a Christian experiencing a deep internal relationship with God through Christ
}

\begin{abstract}
The study aims to define the possible essential characteristics of a Czech teacher of religious education today. First, its audience is informed about a piece of empirical research carried out in the Czech Republic and German speaking parts of Europe. This builds the theoretical framework for a qualitative probe of the religious education teacher's personality, as such. The study is based on data analysis of a focus group of religious education teachers from České Budejovice. The final interpretation finds a certain type of the religious education teacher, which was identified in the interview and creates the possibility of further empirical research.
\end{abstract}

Key words: Personality of a religious education teacher, focus group, professional identity of a religious education teacher, identification of a religious education teacher with the Church

\section{Author contact}

\section{Assoc. Prof. Dr. Ludmila Muchová}

University of South Bohemia in České Budějovice

Faculty of Theology, Department of Pedagogy

Kněžská 8, 37001 České Budějovice

muchova@tf.jcu.cz 